\title{
Liaison Interpreting in the EFL Classroom: A Case Study
}

\author{
José Igor Prieto Arranz \\ University of Oviedo
}

iprieto@correo.uniovi.es

\begin{abstract}
Leaving aside old prejudices against the use of translation in foreign language teaching, the new integrative approaches show how translation (and interpreting)-based activities can also potentially fall into the communicative task category. Liaison interpreting is one such and it is our aim in this paper to investigate how it works with a group of 4th year English Philology students at the University of Oviedo. Results being clearly positive, and taking into account such factors as the importance of the student's $\mathrm{L} 1$ in the learning process, the enormous array of translation-communication strategies produced and the intercultural dimension present in every translation context, we shall finish by arguing for the inclusion of this kind of activities in the L2 classroom.
\end{abstract}

As follows from the title, the field of study this paper will focus on is not so much translation studies as applied linguistics in Foreign Language Teaching (FLT). This should indeed not surprise the reader given the interdisciplinary status of this fascinating discipline (Els et al. 1984: 127) whose main aim is a better understanding of the learner's interlanguage and learning, acquisition and communication processes and strategies so that the quality of FLT might be constantly improved (Corder 1977:64).

Needless to say, no definitive account has so far been provided of the features characterising a good foreign language teacher even though no one would seriously object to his/her duty to stimulate the learner's work by fostering motivation and provoking interest, a task in which the methodology chosen certainly plays a major role (Bocanegra 1997: 250; González Cruz \& Henríquez 1997: 132). 
Living as we do in the communicative era in FLT it follows that we shall abide by the principles of the communicative approach. Several remarks should however be made on this point. The communicative approach as we understand it is what Sánchez refers to as an "integrated" communicative approach $(1993 ; 1997: 196-217)$, a truly unrestricted method which, unlike previous "strong" versions, does not fail to recognise the essentially multifarious nature of communication and, accordingly, of the so-called communicative tasks.

Moreover, this new approach has also been influenced by new appraisals of the role played by the student's $\mathrm{L} 1$ in the foreign language acquisition process. The obvious shortcomings of the old grammar-translation method were made up for with the introduction of a series of "direct" methods -to which the "strong" versions of the communicative methods are direct heirs- simply banning any use of the L1 in the L2 classroom. Fortunately, cognitive learning theories contributed to showing how wrong such a position was (Lavault 1985: 15-16; 85-86; Chuquet \& Paillard 1987: 53; Ladmiral 1987: 12; Sopena-Balordi 1987: 43; Tudor 1987: 268; Villegas 1987: 46; Nadstoga 1989: 109; Rose 1989: 19; Wilss 1989: 93; Newmark 1991: 61-62). Whether we like it or not, the foreign language student enters the classroom endowed with a pre-established linguistic (and cultural) baggage we cannot pretend to ignore. It is therefore highly convenient that we should overcome the old behaviourist prejudices and use that baggage in the students' favour.

This is precisely where translation (and interpreting) activities, long despised in FLT circles, can play a significant role. Thus today we can quite safely talk about the increased use of such exercises in Europe, obvious in France -where they were never given up altogether-, incipient in Spain and notably influential on the other side of the Atlantic. Theorists and practitioners contrary to this tendency hold that translation fosters L1 transfer. However, this is a fact that has not been sufficiently proved (Weller 1989: 44-45; Pegenaute 1996: 115) and, even if it were so, we believe translation could be an excellent exercise to show the learner both the dangers of transfer and the means to reduce it.

What must remain clear is that there is a wide range of perfectly communicative translation-based activities for both teacher and learner to profit from, as Lavault (1985), Krawutschke (1989) and Palacios \& Seoane (2000) engagingly show. One such is what Niedzielski \& Kummer call "liaison interpreting", by which term they refer to any situation in which two or more people who do not speak each other's language manage to communicate thanks to a third person who does (1989: 139).

Such a simple scheme can however give rise to an enormous array of communicative situations, all of which being perfectly plausible and familiar to most of us. Drawing on this, we have devised a situation in which an American -who, needless to say, does not speak Spanish- visits our region, Asturias, for the first time and has been directed to a local inhabitant who will provide her with all the information she wishes to know about the area. Since neither of them speaks each other's language, they require a third person-the studentwho will act as a bridge allowing communication to flow effortlessly. It must be said that we decided on this -and not any other- topic on the grounds that it should be familiar to any 
Asturian student, in the hope that it would consequently determine their involvement in the activity.

Given that none of our students had previously practised liaison interpreting in class, we decided to devise a case study so as to test the performance and adaptability of this activity to a particular group of advanced students of English and to all advanced students in general (Brown 1988: 2; Nunan 1992: 75-77). Although case-study techniques exist allowing for both quantitative and qualitative research methodologies (Cohen \& Manion 1989: 120ff), we decided on the latter especially due to the small number of students we knew would take part in the study (according to their teacher, only 21 attend classes regularly). Another important factor was our interest in carrying out the test in as natural a context as possible, one which should not remind participants of the typical laboratory setting, and in this sense qualitative methods also proved quite useful. After all, it was a field study that we intended to carry out, observing the group of students from within so that they could perceive as few strange elements as possible. Thus, students were told that two sessions would be taught by someone different from their usual teacher and that the first of them would be devoted to translation. However, they were not told that it would all be part of a research project, much less its aims so that the new person in charge of the class could be regarded as yet another teacher and not as a researcher.

\section{Preparatory session}

Given that the interpreting session would obviously foster the appearance of some specific vocabulary we thought it fit to structure the first of the two sessions we would have with them as a kind of preparatory lesson to the main interpreting session. Thus, we selected a 4-page text taken from a tourist leaflet (the English translation of a Spanish original) which dealt quite comprehensively with a variety of topics concerning Asturias (geography, cuisine, History, art, customs and folklore...) and handed it round to them in advance. That first session was mainly devoted to critically analysing the text and the strategies the translator resorted to in it but it also provided excellent training for the future "interpreters".

The preparatory session was held on 3 April 2000 from 5 to $7 \mathrm{pm}$. English was the only language used in it and the total attendance amounted to 15 people. This done, the group of students were ready to face the liaison interpreting activity which we will now go on to describe.

\section{Liaison interpreting}

\section{Introduction}

Our main aim was to test the applicability of liaison interpreting activities in a communicative FLT context. Thus, from a linguistic point of view, we were especially interested in analysing the different communication strategies students could resort to, given that they are essential resources for them to make up for their inevitable competence 
limitations. The session was also meant to practise vocabulary first introduced in the previous session. Lastly, we also wanted to know the extent to which activities of this sort affect the student's affective filter.

\section{Method}

\subsection{Participants}

Eleven students (one man and ten women), all of them students from one of the $4^{\text {th }}$ year English language groups in English Philology at the University of Oviedo, took part in the activity, out of whom ten had attended the preparatory session. Consequently, we will essentially consider the data provided by the latter. No pre-selection was made: it was our aim to work with the group as a whole, as a single unit. Besides, the data contained in a questionnaire the students were asked to fill in after the preparatory session suggested that the possible differences in age and competence would not be relevant.

In our opinion, the low number of students attending this session could be attributed to the logical lack of interest due to their knowing that it would not be taught by their regular teacher and not as a consequence of their being either afraid of, or nervous about, a possible test, since they did not know what the session was going to be about.

We will refer to the students by using a numeral marker instead of their names. The list of the students attending the preparatory session was alphabetically arranged, each student receiving a number from 1 to 15 . Additionally, the only student who did not attend that session was given Number 16. Accordingly, participants in the liaison interpreting activity will appear as $2,4,7,8,9,11,12,13,14,15 \& 16$.

\subsection{Materials and instruments}

Simplicity dominated the whole study. The list of materials and instruments used is the following:

-A sheet in English containing the instructions for students to follow throughout the session (see Appendix A)

-A JVC VHS (GR-AX360) compact video camera and two 45-minute TDK E-HG Hi-Fi VHS-C videotapes. Thus, the session could be recorded and analysed far more rigorously than with an ordinary class diary.

-A questionnaire to be filled in at the end of the session. It was meant to complement our analysis of the videotaped material. It was written in Spanish to facilitate the students' task (see Appendix B). 


\subsection{Procedure}

The session took place at the English Seminar Room, Faculty of Philology, University of Oviedo, on 4 April 2000 from 5 to $6.30 \mathrm{pm}$. We chose this room because of its cosiness, which would undoubtedly provide a more familiar and relaxing environment than that of an ordinary classroom.

The instructions sheet was handed round as students arrived and explained accordingly. The only language used throughout the whole session was English. The interlocutors were introduced simply as Carroll and Patri and students were told that neither of them spoke each other's language, thus emphasising their instrumental role in making communication succeed.

The interlocutors and the interpreter sat at a small table right in the centre of the room. The students were seated in a semicircle around the central table. The camera was placed at a convenient distance both allowing a good recording quality and avoiding excessive interference.

The interlocutors, who actually spoke each other's language, were chosen because of their personal qualities. Carroll had already had a good deal of experience abroad and was at the time in charge of a group of American students at the University of Oviedo, while Patri was the linguistic counsellor in the English-Spanish tandem programme at the University of Oviedo. This means that both interlocutors were especially sensitive to the linguistic and cultural problems that would certainly arise during the session.

Students were told that they would take turns and perform the interpreting function for an average of some five minutes. The researcher, who appears in the transcript as Igor, intervened only occasionally to organise the turns, calm down and relax students when necessary, provide occasional help to both interpreters and interlocutors and lead the conversation in a given direction, although this only happened once. Both interlocutors and researcher had met previously and dealt with the topics that could come up in the conversation -although a script-based conversation was avoided, the session was meant to help the students practise the vocabulary learnt the day before.

Once all the instructions had been given, the session started when the first student sat at the table. Nerves inevitably made their appearance during the first few minutes, although they were gradually overcome and communication eventually went on smoothly. After some 40 minutes, there was a 5-minute break for students to relax, which we used to replace the first videotape with a new one. As an anecdote, we could mention that the last student to take part in the experiment, who had initially proved reluctant to be taped, eventually made no objection to the camera taping her when the time came for her to do her interpreting share.

\subsection{Analysis}

We feel we should justify our using a video camera during the session. It was our aim to get a detailed account of the students' performance without their perceiving it too visibly. Note- 
taking, therefore, was immediately discarded for it would meet neither of our aims. Audio recording was another option but it would have been too visible (a tape recorder on the table would not have been too much of a help for the student to relax) and it would have failed to capture the paralinguistic and non-verbal aspects of communication. The video camera, on the contrary, provided us with the most comprehensive material while at the same time went largely unnoticed by the students given its small size and its rather discreet position in the room.

A full transcript of the session was then made by the researcher, including descriptive notes for non-verbal and paralinguistic aspects when necessary. Unfortunately, obvious space limitations prevent us from including it in this paper and only relevant extracts will therefore be offered.

When analysing the material, several questions must be borne in mind. First of all, we cannot forget we are dealing with an interpreting session set not in a professional context but in the L2 classroom, where interpretation must always be regarded as a means and not an end in itself. Secondly, interpreting involves the use of exclusively oral language, which directly determines not only the style but also the syntax and lexis used. In oral speech, any native speaker will make mistakes (which s/he sometimes corrects), break off, make unnecessary repetitions, even stammer... All these are features clearly to be avoided in a written context but must necessarily be admitted in ours. Finally, we felt we had to concentrate not so much on the possible translation or purely linguistic mistakes as on the different resources used by the students to carry out effective communication. We are therefore referring to strategies which would undoubtedly be seen as communication strategies in a normal L2 context but which can also be regarded as interpretation strategies here; hence their twofold interest.

\section{Results}

\subsection{Translation-communication strategies}

\subsubsection{The cooperation principle}

Once the whole text has been analysed it can be inferred that the students are fully conscious of the dynamic, interactive nature of oral communication. Whenever communication takes place, there must necessarily be at least a sender and a receiver who need not limit themselves to exchanging information but also help each other to achieve effective communication. This, which could be referred to as the "cooperation principle" in communication, can be seen in the performance of every single student in many different ways.

Thus, all students provide ample evidence of their need for feedback from the interlocutors, so that they can check that the message has been effectively put across; obvious use of synonyms also appears in three students to facilitate Carol's comprehension, 
whereas non-verbal signs are used throughout to either transmit or complement meaning. This is especially common in Carroll's parts:

-4: If you want to practise sport, you can train walking from here up to there.

Carroll: Just walking from here up to there... (She touches her front with her hand indicating fatigue and exhaustion).. That's enough!

Group: (Laughs).

4: Que es suficiente con ir hasta allí.

$[\ldots]$

-Carroll: 'Cause it's... we have cider .. the juice. I've had it here and it wasn't like juice... it was more (gesticulates with her hand) a mix of vinegar and juice.

-Group: (Laughs).

-Carroll: Is it common here... in Asturias? [...]

$[\ldots]$

-14: You want a ... camping or just free in the mountains?

-Carroll: Just... we have a tent, we can just... (hits the table) ... pitch it anywhere.

-14: Que lleva la tienda y que pueden ponerla donde quiera.

A good example of interaction between interpreter and interlocutors can also be seen in the following excerpt:

-Patri: [...] Si conoce las residencias universitarias, Colegio San Gregorio y Colegio América, o puede preguntar por ellos porque más o menos es fácil que le digan dónde están, pues está en medio de los dos colegios.

-4: You know the dormitories for students? Colegio San Gregorio...

-Carroll: No, but what is the name of it? (4 does not understand her and Carroll repeats). What is the name?

-4: Colegio San Gregorio. Gregorio (Carroll writes) (To Patricia) ¿Y cuál es el otro?

-Patri: El Colegio América.

Note that 4 does not translate literally. On the contrary, she directly asks Carroll whether she knows the dorms, for -depending on her answer- the strategy she will then use will be different. Moreover, Carroll perceives that 4 has not understood what she has just been told thanks to the expression on her face. Lastly, 4 does not hesitate to ask Patri for help when her memory fails and it is worth pointing out that this will also happen on some other occasions.

The interlocutors also played an essential role in calming down the interpreters whenever they felt some difficult linguistic or cultural mismatch was about to take place:

-7: You can go to ... sidreria? to a sidreria??? (checking whether Carroll knows the term).

-Carroll: Oh, great, I saw some. I saw some (calming her down).

When 7 realises how difficult it would be for her to find an appropriate English term for sidrería she chooses to preserve the ST term making sure Carroll understands its reference. 
Carroll perceives how worried she is and calms her down, adding that she does know the term.

There are also cases in which this cooperation gives rise to hilarious situations. When talking about meals, 8 feels the need to explain the somewhat peculiar Spanish meal times, forgetting momentarily about his bridging function between Patri and Carroll:

-Carroll: Two o'clock for lunch?

-8: Yes (Group laughs)... and they stay there till... till you want really... to the pubs...

-Carroll: Err...so you have lunch at 2 or 3 o'clock before dinner.

-8: Well, dinner is not really... not before 8 . And 8 is ... oh sorry, sorry, sorry! ( 8 realises he is talking to Carroll and not translating for Patri; group laughs). I'm very sorry. (Igor calms him down, although he reacts in a very professional way and says he should limit himself to interpreting).

Another relevant aspect is that the different interpreters do not hesitate to ask the interlocutors for additional information in order to reflect the intended meaning in their translation. This is an extremely useful strategy we believe the L2 learner should always be encouraged to use. Again, student No 8 provides a good example:

-8: And different squares. It's the centre, the old historical centre. And there are different pubs there, clubs...

-Carroll: Is it safe?

-8: Sí, que si es seguro, desde el punto de vista... me imagino que de... (To Carroll). Safe.. What do you mean by safe? Yeah, explain it, please.

$[\ldots]$

-Patricia: ¿Seguro en el sentido de que pueda haber violencia en la calle?

-8: Sí, no lo especificó pero sí. (To Carroll) Well, you mean safe about being quiet, with no violent people, or what do you mean by safe?

Alternatively, other examples appeared in which this strategy was motivated by partial or even total incomprehension, in which cases repetition was required by both interpreters and interlocutors.

Moreover, interpreters had also been encouraged to resort to the group occasionally since they were also an integral part in the communication that was taking place:

-Patri: (To 9). Dile que en la Catedral, bueno en el Museo de la Catedral, está la Cruz de la Victoria y la Cruz de los Ángeles, que son un símbolo de Asturias.

-9: In the Museum of the Cathedral you can see the Cruz de la Victoria... the... (looks at group). ¿Cómo se dice "cruz"?

-Group: Cross.

-9: Cross. Cross of Victory and the Cross of the Angels, which are typical symbols from Asturias.

[...]

-11: Las Caldas. 
Patri: Dile que hay un campo de golf allí.

-Igor: (To Patri). Y un balneario, ¿no?

Patri: Y un balneario.

-11: There is a bath... a bath.... (To group). ¿Cómo se dice balneario?

-Group: Spa.

-11: Spa. Ah, there is a spa at the end of the path.

In certain cases, the interlocutor's intervention helps the interpreter realise that what s/he has just said is not grammatically correct or at least not very idiomatic. On such occasions, this communication strategy becomes a learning strategy for the learner. Let us see one of these cases, in which the interpreter is listing the different dishes that could be savoured at a typical espicha until the turn comes for productos del mar, which she translates literally and which Carroll understands, although she cannot help providing in turn the correct English term:

-Patri: Pues, por ejemplo, cabracho... (looks at Igor, conscious of the difficulty of the translation; group laughs)...que es un pastel especial de pescado.

-7: For example, cabracho. Cabracho is a special ....

-Igor: (helping 7). Fish pie, I would say.

-7: Fish, fish pie.

-Patri: Y muchos productos de la mar.

-7: And especially products from the sea.

-Carroll: Ah, sea food!

\subsubsection{Summary}

Without doubt, this was the second most frequently-used strategy. Summarising is virtually inevitable in interpreting -our processing limitations force us to make the best of our efforts and select information, thus eliminating everything considered redundant or secondary from the point of view of the information value contained. On the other hand, this is an extremely useful strategy for the L2 speaker, whose always deficient competence makes him/her skilfully manage his/her limited resources and summarise what would otherwise be said far more extensively in his/her L1.

Examples are ubiquitous and, as a sample, we will reproduce one which is especially funny. It clearly shows the interpreter's practicality by only translating the American interlocutor's last question, thus obviating all the introductory part, although she is eventually made to allude to it:

-Carroll: Great, two questions: that... what we said, to organize weekend excusions, and that kind of thing. And also questions about daily life: where to go to the gymnasium, where to go to internet... so well, to begin, is there a gymnasium close to University?

-2: Que si hay un gimnasio por aquí cerca.

-Patri: ¿Te ha preguntado eso?

-Group: (Laughs). 
-2: Y más. Bueno, que sî, que era eso. Lo de los fines de semana, pues cosas de la vida diaria, los gimnasios por aquí cerca, internet...

\subsubsection{Explanation}

Explanation is usually resorted to when the translator comes across a concept which is not lexicalised in the target language. In an L2 context, explanation may appear whenever the learner does not know a given term in that language but wants, however, to put its meaning across to his/her interlocutor. Both possibilities can of course be found in our case.

A good example we have already seen when 8 felt the need to explain to Carroll the rather confusing Spanish concept of mediodía. But this strategy is most frequently used to fill in gaps in the interpreters' lexical competence. Note, for example, how 4 and 13 manage to explain the meanings of instalaciones and basílica, respectively:

-Patri: Sí, mientras tengan un carnet universitario pueden utilizar las instalaciones de la universidad.

-4: As long as they have the ID card of the student, they can use the... the... (she cannot find an appropriate translation for instalaciones). The... (to Patricia) ¿instalación? (She proceeds to explain its meaning). The swimming pool, the gym...

$[\ldots]$

-Carroll: $\mathrm{OK}$, is it a cathedral?

-13: ¿Es una catedral?

-Patri: Es una basílica.

-Grupo: (Laughs). (Conscious of how difficult it is to translate the term).

-13: It's a type of, a type of... It's not as big as a cathedral, but it looks like a cathedral. It's a...

-Patri: Dile que es tan grande como una catedral, pero que...

-13: It's as big as a cathedral, but it has another term.

-Carroll: OK.

\subsubsection{Rephrasing}

This is the next strategy on the scale of the most frequently-used resources. Through it the interpreter deviates from the ST's syntactic structure while trying to produce a TT with as close a content as possible. A clear example of a rebellious attitude towards the ST from a purely functionalist point of view, there is no choice for the $\mathrm{L} 2$ learner but to resort to it given the logical limitations of his/her syntactic or even lexical competence.

In our context, we have come across examples involving rephrasing with both Spanish and English as the target language. In this sense, 2 finds it difficult to produce a Spanish NP for regular courses. Consequently, rephrasing is called for:

-Carroll: No, they're studying here at University but not regular courses... they're studying Spanish here.

-2: Que están estudiando aquí en la facultad, pero... no es como si vinieran a clase normalmente. Son más bien de español.[...] 
15 , on her part, feels it necessary to reduce what would otherwise be excessive rhetoric in English:

-Patri: Ah, bueno... hay cientos de playas en la costa asturiana. No muchas excesivamente grandes por la... bueno, porque es una región muy montañosa... (She signals for 15 to translate).

15: There are hundreds of beaches in the coast in Asturias, but many of them are quite small because of the mountains, you see... and they are very beautiful, but not very big.

\subsubsection{Interpretation of a potentially ambiguous ST}

On some occasions, the student has no choice but to venture on the spur of the moment an interpretation of a ST which is for him/her potentially ambiguous, either because the original phrasing is not clear enough or because his/her $\mathrm{L} 2$ competence, which could never equal a native speaker's, makes him/her falter. This clearly shows the incredible mental effort required when carrying out an activity of such characteristics. Let us see a couple of representative examples taken from 15 's output. In the first case, the ambiguity she feels the ST has is caused by her imperfect knowledge of the term ocean. In the second, however, she refines Carroll's too generic expression:

-Carroll: I'd... where's the best place to go... to see the ocean here?

-15: Well, (Group laughs)... dice que dónde está el mejor sitio para ir a ver el océano, pero yo creo que le deberíamos explicar que no tenemos océano.

-Patri: ¿El océano?

-15: Dice el océano, pero supongo que se refiere al mar.

-Patri: El mar... bueno, no importa. A la costa.

-15: ... Que dice que cuál es el mejor sitio, el más aconsejable... supongo que se refiere a puntos turísticos.

[...]

[Surf on the beach in Gijón]

-Carroll: (nods). And is there anyone who can teach you how to do it?

-15 : Si hay algún instructor que te pueda ayudar a hacer surf.

\subsubsection{Improving the ST}

Occasionally, the ST is improved in the translation process. When this is so, what the interpreter does is to interpret the ST's function and then make some syntactic and lexical choices to emphasise it. This is something the students were familiar with since it was one of the topics dealt with in the preparatory session on tourist text translation. 15's intervention is especially productive in this sense. She is fully conscious that the Spanish interlocutor is trying to promote Asturias and she clearly decides to emphasise that function. At a certain point, Patri encourages Carroll to visit the Llanes and Tapia coastal areas, with no additional comment. 15 translates it adding: "And both places are quite good for tourists [...]". Further on, Patri praises the charm to be found in the beaches around Llanes. In her 
translation, 15 adds that "they are not very crowded". A similar effect can be seen in the following extract about surfers on the beach in Gijón:

-Patri: Pues no lo sé si hay una escuela de surf... pero bueno... siempre hay mucha gente practicando ese deporte, entonces... podrías... hacer amigos allí... (Group laughs).

-15: There might be some instructor to teach you, but in any case, there are always many people surfing in the beach, so they can teach you and they are very friendly.

\subsubsection{Translation avoidance}

Avoidance is extremely useful when cultural difference is far too extreme for communication to take place. Thus, the translator can choose not so much to adapt, explain or reproduce that difference as to eliminate it.

Even if in our specific context translation avoidance may look as if the interpreter had forgotten to account for a certain part of the ST, there are two cases in which we consider it has been consciously used. In one of them the Spanish interlocutor describes the typical dishes to be found at one espicha and she inevitably refers to the popular tapas, a concept the interpreter (student No 7) simply chooses not to mention.

The second context in which avoidance appears fully justifies the interpreter's decision. In this case, the Spanish interlocutor jokes about the hard times the mining industry is going through in our region:

-16: In this cuenca you can see the mines but from the exterior of the mines.

-Carroll: You can't go in?

-16: No pueden entrar, ¿no?

-Patri: Sí, si les dan trabajo, sí (Group laughs).

16: (Laughing). Quiere decir en el Caudal.

Patri: No, en ninguna mina, en ninguna.

16: You can't go inside any mine [...].

Asked whether mines can be visited, the Spanish speaker makes an ironic comment which would certainly require some additional explanation the interpreter considers not worth going into and therefore opts to avoid it altogether.

\subsubsection{Adaptation}

We had better see this in the light of a very clear example. As was to be expected, the topic of the peculiar Spanish weather comes up at a given point. The context was as follows:

-Patri: En la primavera.

-14: In the spring.

-Carroll: April, May...?

14: (Looks at Patricia in an inquisitive way).

-Patri: Cuando deje de llover. 
Group: (Laughs).

-14: When the rain stops.

-Carroll: When is the rain gonna stop?

-Group: (Laughs).

-14: Que cuándo va a parar la lluvia.

-Patri: Que no lo sé.

(Carroll touches wood).

-14: Nobody knows.

As can be seen, 14's translation of Patri's "Que no lo sé" is not precisely an equivalent. What she does here is to emphasise the speaker's uncertainty, thus somehow suggesting the typical instability of the Asturian weather, very much in keeping with Carroll's despair.

\subsubsection{Self-correction}

Lastly, another tool frequently used during the session was self-correction, mainly involving lexical options. A particularly interesting instance involves the translation of the term trip into Spanish, since it shows that the exercise did its part in helping the students do away with their inevitable but restrictive binary L1/12 equivalents. Thus, Spanish learners normally associate trip with the Spanish term viaje, even though the content of the English item is wider and therefore includes concepts which the Spanish language expresses through other lexical items.

At the very beginning of 13's intervention, Carroll refers to the trips to the mountains she would like to make. 13 automatically translates trips as viajes, even though she quickly perceives the context and realises the speaker refers to "one-day trips", which makes her correct herself as follows: "Ya tenemos los viajes, o sea, las excursiones a las montañas...".

Once we have reached this point, we cannot but briefly deal with the different errors the students made. And we say "briefly" for several reasons: first, even if the session's total running time amounted to one hour and twenty minutes approximately, the number of mistakes made by the students could hardly have been lower. Secondly, we cannot forget we are in an L2 learning context and, consequently, however proficient the students may be, they can never reach native speaker standards. Third, they are not professional translators or interpreters either, which is the reason why we will follow rather flexible criteria when spotting translation errors. Lastly, space limitations prevent us from giving an exhaustive account of all the mistakes committed by our students, which would be useless if the full transcript has not been read first.

\subsection{Translation errors}

We have only spotted a few instances of pure translation errors, that is, mistakes not due to a deficient competence in either of the two languages involved. The first of them appeared at the very beginning of the session, in the following context: 
-Carroll: They [my students] do. They have class every day, now. But mostly what I'm looking for is for weekends, to have excursions, ...

[...]

-2: [...] Que tienen clase todos los días por la tarde, pero lo que quiere es más o menos para los fines de semana, excursiones...

It is clear that that 2's translation captures the essence of the ST, but she adds an extra piece of information that cannot possibly be inferred from it: that Carroll's students attend afternoon and evening classes at college. This is, therefore, a case of overtranslation.

Another mistake has to do with the description of the Archaeological Museum's collections, which, according to the Spanish interlocutor, covers all historical periods from the Celts. It is true that the way she puts it can give rise to several interpretations, but 9's translation ("it is... has things from the Romans to the times... now") makes the listener get an absolutely wrong idea of the museum's collections: being an archaeological museum, it has no room for contemporary art.

Somewhat less serious is 11 's statement that Pre-Romanesque art can only be found in Asturias, when the ST went "casi sólo existe aquí".

The two remaining mistakes have to do with 16's description of the Mining Museum. Drawing on no previous evidence, she wrongly describes it as "a reproduction of a mine". Later on, she inexplicably chooses to translate a description of it that the very Spanish speaker has previously corrected:

-Patri: Sí, es un museo... está sobre una antigua mina. No está. Es una antigua mina.

-16: The museum is on a... on a... on an old mine (Carroll nods), it's on an old mine.

In any case, errors of this kind have been virtually non-existent.

\subsection{Linguistic errors}

Suffice it so say that we took into account the principles stated earlier on, and we then proceeded to classify the errors into 6 different categories (lexical, semantic ${ }^{1}$, syntactic, morphological, collocational and phonological). The results can be seen in the following tables:

\section{Type of error}

Lexical

Semantic

Syntactic

Morphological

Collocational

Phonological

\section{Distribution of errors per types}

\section{Number of errors}

12

38

19

1

6

3

TOTAL: 79 
Distribution of errors per student

\begin{tabular}{|l|l|l|l|l|l|l|l|}
\hline Student & Lexical & Semantic & Syntactic & Morphol. & Colloc. & Phonol. & Total \\
\hline 2 & 1 & 4 & 1 & 0 & 0 & 0 & 6 \\
\hline 4 & 0 & 4 & 3 & 0 & 1 & 1 & 8 \\
\hline 7 & 2 & 3 & 1 & 0 & 0 & 0 & 6 \\
\hline 8 & 1 & 2 & 0 & 0 & 0 & 0 & 3 \\
\hline 9 & 2 & 4 & 4 & 0 & 0 & 1 & 11 \\
\hline 11 & 2 & 4 & 7 & 0 & 0 & 0 & 13 \\
\hline 12 & 1 & 4 & & 0 & 1 & 0 & 6 \\
\hline 13 & 0 & 3 & 0 & 1 & 2 & 1 & 7 \\
\hline 14 & 2 & 3 & 1 & 0 & 1 & 0 & 7 \\
\hline Student & Lexical & Semantic & Syntactic & Morphol. & Colloc. & Phonol. & Total \\
\hline 15 & 0 & 7 & 2 & 0 & 0 & 0 & 9 \\
\hline 16 & 1 & 0 & 0 & 0 & 1 & 1 & 3 \\
\hline
\end{tabular}

Special reference should be made to students 8 and 16, whose number of errors is remarkably lower than the average, as well as to students 9 and 11 , whose number is somewhat higher. Apart from that, the distribution is fairly regular, as can be seen in the tables above.

On the other hand, it is not surprising that those errors most frequently made by the students should be of a lexical / semantic kind, which suggests obvious deficiencies in the students' lexical competence. We should not forget that these are advanced students and it is therefore normal for them to show more limitations in their lexical competence (lexical items are virtually infinite, and not even a native speaker will ever be able to master them all, whereas syntactic rules are part of finite and fairly stable set).

It must also be said that a selection of the mistakes noted above, together with what would have been considered "correct" in each case, was handed round to the students a few days after the session was held (see Appendix C). Thus, they received some kind of feedback for them to reflect on how to improve their performance.

We will now proceed to give an account of the data provided by the questionnaire the students had to fill in after the interpreting session

-Question 1: Usefulness of the preparatory session. Answers could not be more in unison in this regard. All students found the session useful (even though there is one who says it was not too useful). Student No 16 does not answer the question since she did not attend the preliminary session.

All students agree that both the topic and the vocabulary dealt with in that session were helpful when it came to facing the interpreting activity. Moreover, two people emphasise that it served them to face the intercultural dimension existing whenever there is communication between two speakers of different languages. Finally, another person stated that it was a useful introduction to translation strategies and resources. 
Questions $2 \& 3$ : The student's affective filter during the session. Again, results are clearly positive. Out of the eleven participants, only two state they felt considerably more nervous than in an ordinary class, whereas five declare they felt slightly more (although not relevantly) nervous. The remaining four felt just as usual.

As for the reason for their nervous state, three people mention the video camera (which was to be expected), whereas two others confess their fear of speaking in public.

However, five students emphasise the pleasant environment achieved together with the efforts on the part of the organisers to calm down the participants.

It is most enlightening that out of all the people who state that they felt nervous, there is only one who says she did not calm down progressively during the session, even though she herself adds this was unimportant because she does not consider she ever felt relevantly nervous.

Such answers confirm that we succeeded in avoiding a laboratory atmosphere. We therefore imagine that our results would not have deviated much had the session taken place in an ordinary class and been led by their usual teacher.

-Question 4: Usefulness of the interpreting session. Answers confirm the absolute success achieved in this sense. Every single participant found the session helpful (or even very helpful, given the unison shown in answering). They all agree that the situation simulated during the session was perfectly plausible and could therefore have happened in real life. The feeling of having done something useful is, then, unanimous.

This is related to the high degree of spontaneity reached, which is again remarked upon by all participants. This proves that our design was correct in that it avoided script-based interventions.

Almost unanimous agreement ( 8 out of 11) was shown on three other important questions. First, students find interlingual exercises to provide "good training to develop linguistic instinct and reflect on similarities and differences between the languages involved". Our arguments about the role of the student's L1 in the L2 classroom are therefore confirmed.

Secondly, there are also eight people who believe this kind of exercise is extremely useful to help students to become fully aware of what we have termed interpretation strategies, which in an L2 learning context can also be seen as essential communication strategies compensating for what will always be a deficient linguistic competence. This is closely linked to the cooperation principle we have been dealing with and in turn allows us to describe the liaison interpreting session as a pure communicative task.

Lastly, there are also eight people who highlight the task's contribution to the learner's self-esteem. Indeed, this activity shows them that their competence is good enough for them to face complex communicative situations like these and even more complex ones. As teachers, we believe that producing this feeling in the learner is one of the highest goals we can aim at.

-Question 5: Should activities of this kind be included in the curriculum? Given the answers to the previous question, no wonder all participants showed their enthusiasm at the idea of having such activities included in the curriculum. In fact, eight students overtly 
believe it should be carried out regularly, whereas the remaining three decide on a lower frequency.

Two comments must be made in this respect. On the one hand, we cannot pretend we are not delighted with the results, since they provide further evidence indicating that the task was fully successful and that the students did have a great time during its course, even if it took longer than the usual one-hour lecture these students are accustomed to.

On the other, we must interpret such answers as an over-enthusiastic response to an activity they have truly enjoyed. We must be cautious with our success and remember that translation in an L2 context should always be a means and never an end in itself. Moreover, we are certain that the students are not conscious of all the work and effort needed to prepare an activity like this, which clearly prevents the teacher from scheduling them with too high a frequency. Another point is the difficulty in finding the appropriate people to perform the interlocutor role in the task, even though it is true that similar activities could be devised in which two students can play those parts. Interesting though this might be, the simulation would almost certainly lose a great deal of realism.',

\section{Conclusion}

The preparatory session fulfilled at least one of its aims: it provided good training for the interpreting session and the students appreciated it accordingly. Besides, in the light of the data gathered from our analysis and the answers to the questionnaire, four conclusions can be drawn:

-Liaison interpreting emphasises the immediate usefulness of the student's L2 as a tool for real communication, based upon interlocutor interaction and cooperation.

-In spite of the opinion of some purists, the L2 classroom cannot ignore real life and pretend that the L2 is the student's only language. Much on the contrary, students enter the classroom with a linguistic background which need not be understood as an obstacle in their L2 learning race. Thus, with the help of activities like the one presented in this paper, the student's L1 can be used to practise and improve their L2, favouring constant comparison -not confusion- between both linguistic systems.

-The frontier between translation and L2 learning becomes blurred once translation strategies can be used as communications strategies, of vital importance when it comes to making up for the learner's inevitably deficient L2 competence.

-L2 learning is not just a matter of acquiring a new linguistic system. It involves a far more complex process in which the learner gets in touch with another way of thinking, with another people; in a word, with another culture. In this respect, translation and interpreting exercises can be extremely useful, since they force the translator / interpreter to be fully conscious of the transcultural dimension that opens up whenever an L2 word is uttered.

We trust, then, we have been able to show how translation and SLT can go hand in hand through a perfectly communicative task in which students have a unique chance to practise and improve their L2 competence and, why not, that of their L1. 


\section{Notes}

1. As opposed to purely lexical mistakes, semantic errors involve the use of a perfectly grammatical sequence from a syntactic point of view, although bearing a different meaning from the one intended by the speaker.

\section{Works cited}

Bocanegra Valle, Ana (1997): "El profesor de lenguas extranjeras como facilitador de aprendizaje". EPOS XIII: 249-273.

Brown, James Dean (1988): Understanding Research in Second Language Learning. A Teacher's Guide to Statistics and Research Design. Cambridge, New York \& Melbourne: CUP.

Cohen, Louis and Lawrence Manion (1989 [1980 \& 1985]): Research Methods in Education. London \& New York: Routledge.

Corder, S. Pit (1977 [1975]): "Error analysis, interlanguage and second language acquisition". In V. Kinsella, ed., Language Teaching and Linguistics: Surveys. Cambridge, London \& New York: CUP, 60-78.

Chuquet, Hélène. \& Michel Paillard. (1987): "Traduire et s'approcher les différences". Les Langues Modernes 1/1987: 53-62.

Els, Theo van; T. Bongaerts; G. Extra; C. van Os and A.-M. Janssen-van Dieten (1984 [1977]): Applied Linguistics and the Learning and Teaching of Foreign Languages (Van Oirsouw, Robert R. trans.). London: Arnold.

González Cruz, I. and S. Henríquez Jiménez (1997): "Sobre actitudes y motivación en el aprendizaje del inglés en la universidad". In J. M. Oro \& J. Varela, eds., Adquisición y Aprendizaje de Lenguas Segundas y sus Literaturas. Santiago de Compostela: Universidade de Santiago de Compostela, 129-134.

Kinsella, Valerie (ed.) (1978): Language Teaching and Linguistics: Surveys. Cambridge, London \& New York: CUP.

Krawutschke, Peter W. (ed.) (1989): Translator and Interpreter Training and Foreign Language Pedagogy. American Translators Association Scholarly Monograph Series Volume III. Binghamton (NY): State University of New York at Binghamton.

Ladmiral, Jean-René (1987): "Pour la traduction dans l'enseignement des langues: "version" moderne des Humanités". Les Langues Modernes 1/ 1987: 9-21.

Lavault, Elisabeth (1985): Fonctions de la Traduction en Didactique de Langues. Apprendre una Langue en Apprenant à Traduire. Paris: Didier Érudition.

Nadstoga, Zbigniew (1989): "Translator and interpreter training as part of teacher training at the Institute of English, Adam Mickiewicz University, Poznan, Poland". In P. W. Krawutschke, ed., Translator and Interpreter Training and Foreign Language Pedagogy. Binghamton (NY): State University of New York at Binghamton, 109-118.

Newmark, Peter (1991): About Translation. Clevedon, Philadelphia \& Adelaida: Multilingual Matters LTD.

Niedzielski, Henry \& Manfred Kummer (1989): "Learning translating and interpreting through interlanguage". In P. W. Krawutschke, ed., Translator and Interpreter Training and Foreign Language Pedagogy. Binghamton (NY): State University of New York at Binghamton, 132-146. 
Nunan, David (1992): Research Methods in Language Learning. Cambridge, New York \& Oakleigh: CUP.

Oro Cabanas, José Manuel \& Jesús Varela Zapata (eds.) (1997): Adquisición y Aprendizaje de Lenguas Segundas y sus Literaturas. Santiago de Compostela: Universidade de Santiago de Compostela.

Palacios Martínez, Ignacio M. \& Elena Seoane Posse (2000): Aprendiendo y Enseñando a Traducir / Learning and Teaching to Translate / Aprendendo e Ensinando a traducir. Santiago de Compostela: Universidade de Santiago de Compostela.

Pegenaute, Luis (1996): La traducción como herramienta didáctica. Contextos XIV / 27-28: $107-125$.

Rose, Marilyn Gaddis (1989): "Must translator training remain elitist?" In P. W. Krawutschke, ed., Translator and Interpreter Training and Foreign Language Pedagogy. Binghamton (NY): State University of New York at Binghamton, 18-25.

Sánchez Pérez, Aquilino (1993): Hacia un Método Integral en la Enseñanza de Idiomas. Estudio Analítico. Madrid: SGEL.

(1997): Los Métodos en la Enseñanza de Idiomas. Evolución Histórica y Análisis Didáctico. Madrid: SGEL.

Sopena-Balordi, Amalia E. (1987): "Revaloriser la traduction". Les Langues Modernes 1 / 1987: 41-43.

Tudor; Ian (1987): "Using translation in ESP". ELT Journal 41(4): 268-273.

Villegas, Jean-Claude (1987): "La peur de traduire ou le complèxe du fort-en-thème". Les Langues Modernes 1/1987: 45-52.

Weller, Georganne (1989): "Some polemic aspects of translation in foreign language pedagogy revisited". In P. W. Krawutschke, ed., Translator and Interpreter Training and Foreign Language Pedagogy. Binghamton (NY): State University of New York at Binghamton, 39-50. Wilss, Wolfram (1989): "Topical issues in translator training at universities" (Gardiner, Jeffrey B. \& Shelley Reid, trans.). In P. W. Krawutschke, ed., Translator and Interpreter Training and Foreign Language Pedagogy. Binghamton (NY): State University of New York at Binghamton, 89-99.

\section{APPENDIX A}

\section{Liaison interpreting}

Instructions

Carroll is an American girl who is visiting Asturias for the first time and she is eager to know more about our region. That is why she has been introduced to Patricia, a local girl who knows quite a lot about it. She will suggest where to go, what to see, what to eat and drink, etc. depending on Carroll's personal interests. The only problem is that they don't speak each other's language and so they need another person to translate for them.

For a few minutes, you are going to be that person. Please take into account that not only two languages but also two different cultures are involved. This means that additional information may sometimes be required.

Note that this is an informal situation and that you'll be talking to real people, present in front of you. Please don't hesitate to tell them about any problem you might have (you may tell them to 
speak up, to slow down, to explain something in another way, to help you with your vocabulary or even syntax in either language...). They are there not only to profit from you but also to help you! Occasional help from the group is also allowed!

If you arrive late, please sit at the back and wait till you're given further instructions.

Enjoy the session and thanks for your cooperation.

\section{APPENDIX B: QUESTIONNAIRE}

1. ¿Consideras que la sesión preparatoria del lunes te ha servido para algo en relación con la interpretación de enlace?

-SÍ: $\quad$-He trabajado vocabulario útil para la interpretación.

-Otros (especificar):

-NO: $\quad$ No tienen nada que ver.

-Otros (especificar):

2. Durante la sesión de interpretación de enlace, ¿te has sentido más nervioso/a o incómodo/a de lo que normalmente te puedes sentir en cualquier otra clase?

-No: -Se consiguió un ambiente agradable y distendido ( $\mathrm{N}^{\circ}$ de alumnos, espacio, disposición de los asientos).

-Las personas responsables se esforzaron por calmarnos.

-Nunca me pongo nervioso/a.

-Otros (especificar):

-Quizá un poco, pero nada relevante (especificar por qué).

-SÍ: -El cambio de aula repercute negativamente.

-Me da vergüenza / me pone nervioso/a estar con un profesor distinto del habitual.

-Me sentí un poco conejillo de indias.

-Me sentí observado/a.

-Otros (especificar).

3. Si has experimentado mayor tensión de lo normal, esta tensión

-Perduró durante toda la sesión.

-Disminuyó conforme avanzaba la sesión.

-Aumentó conforme avanzaba la sesión.

4. La actividad me ha parecido

-ÚTIL: $\quad$-Supone una situación que puede suceder perfectamente en la realidad.

-Te anima ver que eres capaz de hacer frente a una situación como la que se reproduce.

-El paso de una lengua a otra puede ser un ejercicio útil y un buen entrenamiento para desarrollar el instinto lingüístico y para reflexionar sobre los paralelismos y diferencias entre ambas.

-Es una actividad más espontánea que la traducción de textos escritos. 
-Potencia mucho más la expresión oral que la traducción de textos escritos.

-Te permite recurrir a múltiples estrategias para suplir tu carencia lingüística (gesticulación, interrupciones, solicitar que se repita lo que se ha dicho o que se hable más despacio, posibilidad de resumir información, circunloquios, comparaciones...). -Otros (especificar):

-INÚTIL: - La tensión te bloquea y tu capacidad de comprensión / comunicación disminuye. -El cambio de un idioma a otro no sirve nada más que para confundirte. En la clase de inglés sólo se debe hablar inglés.

-La traducción / interpretación no tiene nada que ver con hablar bien o mal inglés.

-Se practica lo mismo que en cualquier clase de conversación, con el inconveniente añadido de que te pones más nervioso/a.

-Otros (especificar):

5. Me gustaría que

-Sesiones como ésta no se volviesen a repetir.

-Sesiones como ésta tuviesen lugar de vez en cuando.

-Sesiones cómo ésta se programasen regularmente.

\section{APPENDIX C: FEEDBACK SHEET}

You said...

Alletism

Products from the sea

Rice with milk

Prevenge

Places where pictures are exposed

Pre-Romanic

Go until

Camping

Bone

Neighbourhoods

Walnut

To expose

Story

Corner (of the road)

Bath

Go out

Since (indicating place of origin)

Carved

From time to time

In the path to

Representation

Town centre
You should have said...'

Athletics

Sea food

Rice pudding

Precaution

Art galleries

Pre-Romanesque

Go to, reach

Camp ground, camp site

Season ticket, voucher

Residents' associations

Hazelnut

To exhibit

History

Turning (of the road)

Spa

Start out

From

Excavated, dug out

At certain times

On the way to

Replica (of an artistic object)

Capital (city) 
Winds

Ciders

Pay something

Enter in a place

On walk, by walking

Equip (VP)

Shops souvenir

Do hiking, do a walk

To hire for some hours
(Sea) waves

Kinds, types of cider

Pay for something

Enter a place

On foot, walking

Equipment (NP)

Souvenir shops

Go hiking, go for a walk

To hire by the hour
Also note :
Movie theaters $(\mathrm{Am} \mathrm{E})=$ cinemas
Student ID(entitity) card
Bear cubs = baby bears
Ocean = sea (in some contexts)
Want someone to do something

Finally, these are some words that were mispronounced during the session. Please check their pronunciation in a good dictionary:

Museum

Catholic 